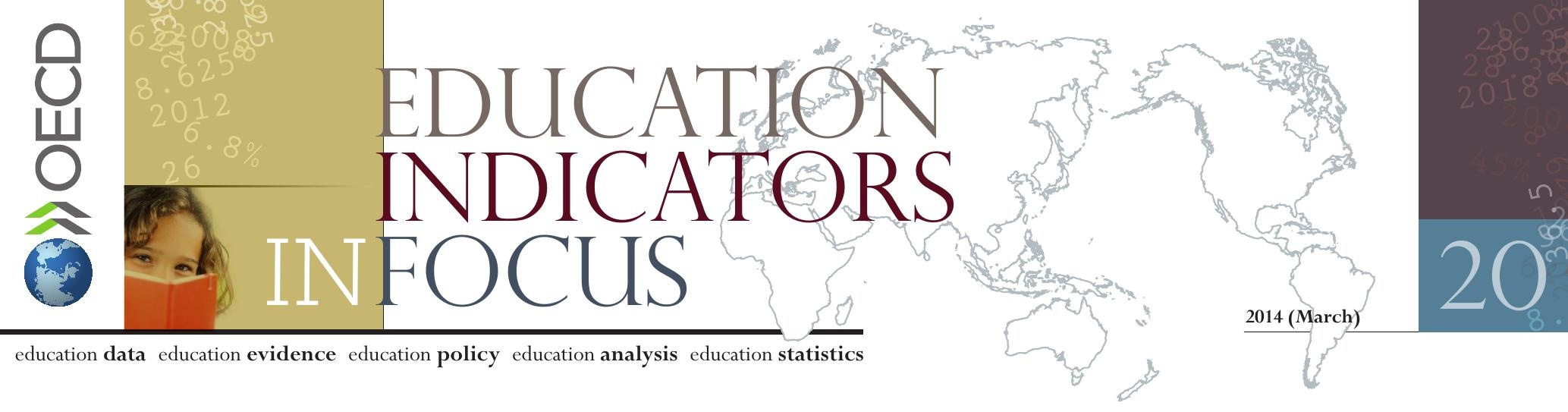

\title{
How old are the teachers?
}

- More than one-third of male primary school teachers in OECD countries are now over 50 years old.

- Across OECD countries, the average age of secondary school teachers has increased by one month every year in the last decade.

- Only a few countries have managed to develop policies which lower the average age of teachers significantly.

- Increasing the numbers of female teachers no longer lowers the average age, $36.5{ }^{3} 8$ as the female teaching workforce is ageing faster than its male counterpart.

The teaching workforce continues to grow older

For several years now, the age structure of the teaching workforce has caused concern. In the Teachers Matter study $(O E C D, 2005)$ the OECD was already pointing out the risks associated with an ageing teaching workforce in terms of teacher recruitment, salary costs and costs associated with retraining older teachers. The evidence shows that the situation since then has not improved, in fact quite the contrary.

As Figure 1 shows, in 2000 the average age of a male primary school teacher across OECD countries was 42.9; in 2011 it was 43.2. The average age of their female colleagues rose from 41.6 to 42.3. Male secondary school teachers were aged 44.1 on average in 2000; in 2011 the average was 44.9. For female secondary school teachers the average age in 2000 was 42.3, while it was 43.3 in 2011. Figure 2 shows that the share of older teachers (those over 50 years old) in the workforce also increased. Among male primary school teachers it was 31\% in 2000 and it rose to 34\% in 2011.

Figure 1. Average age of teachers

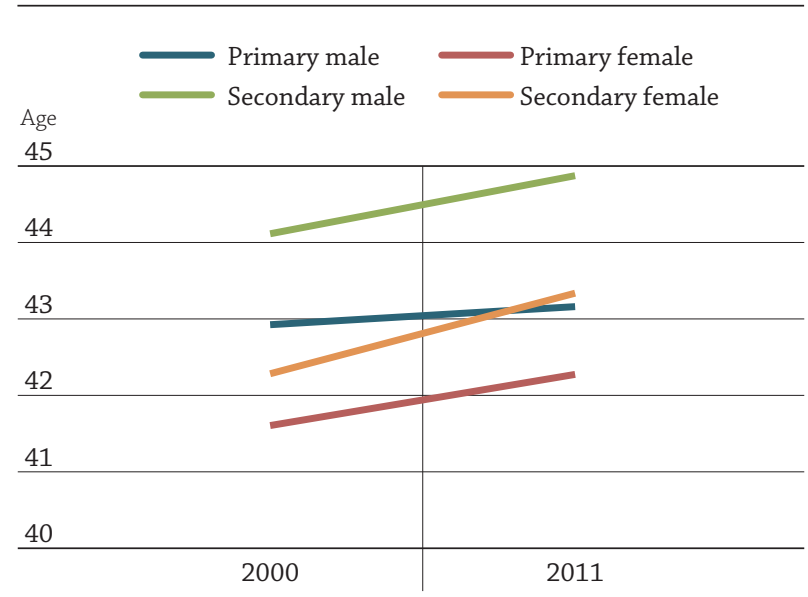

Source: OECD Education Database (available at $h t t p: / / s t a t s . o e c d . o r g)$.
Figure 2. Share of teachers over 50 years old

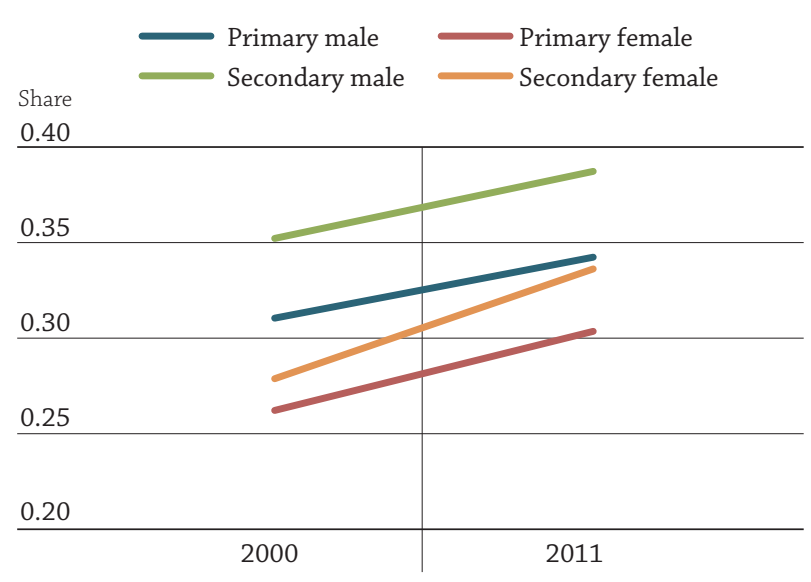

Source: OECD Education Database (available at http://stats.oecd.org). 
Among their female colleagues the share of older teachers increased from $26 \%$ in 2000 to $30 \%$ in 2011. Among secondary school teachers the share of older teachers increased from 35\% to $39 \%$ for males, and from $28 \%$ to $34 \%$ for females. These data also show that on average, primary school teachers are younger than their secondary school colleagues, and that female teachers are younger than male ones at both levels.

The ageing of public-sector professionals is not unique to teachers. The ageing of medical doctors is also raising concerns in many countries. In 2011, nearly one-third of all doctors on average across OECD countries were over 55 years of age, up from one-in-five in 2000 (Jensen et al., 2012). Equally, civil servants in central governments are much older on average than the labour force as a whole: in 2011, 33\% of civil servants were over 50 across OECD countries, compared with 27\% in the labour force as a whole (OECD, Public Employment database). With 36\% of secondary school teachers over the age of 50 , however, teachers are well above the average even for civil servants.

\begin{abstract}
Skewed age distributions
Various national circumstances and policy measures determine the age distribution in the teaching workforce, making it rather difficult to define an "optimal" age distribution. But we can assume that there should be a balance between younger and older teachers. We can thus calculate an age distribution index by dividing the share of younger teachers ( $<30$ years old) by the share of older teachers ( $>50$ years old). Given the average graduation and retirement ages, an optimal age distribution index would be around 0.50 .
\end{abstract}

In 2011, the average age distribution index for OECD countries with comparable data was 0.42 for primary school teachers, 0.33 for lower secondary school teachers and 0.24 for upper secondary school teachers, indicating that the age structure is very much skewed towards the older generations. There are only a few countries which have a more optimal distribution: Belgium, Ireland, Israel, Korea and the United Kingdom have an index greater than 0.75 for primary education. For upper secondary education, Canada, Chile, Korea and the United Kingdom have an index greater than 0.50. But Germany, Italy, Luxembourg and Sweden have an index lower than 0.20 for primary education and Germany, Iceland and Italy have an index lower than 0.10 in upper secondary education.

In some countries the share of teachers over 50 years old is exceptionally high. In Italy the situation is quite dramatic: $62 \%$ of its secondary school teachers are over 50 and for every 100 teachers over 50 there is only 1 teacher under 30. In 2011, 62\% of male primary school teachers in Germany were over 50, with $56 \%$ in Italy and $53 \%$ in the Netherlands. For secondary schools, 55\% of the male teachers in Germany were over $50,52 \%$ in Iceland, $67 \%$ in Italy and $55 \%$ in the Netherlands. In all these countries, the percentages for female teachers were much lower, only exceeding $50 \%$ in Italy where $60 \%$ of the female teachers were older than 50.

Figure 3 relates the average age for secondary school teachers to its average annual change over the period 2000-11. ${ }^{1}$ It shows which countries have a relatively old secondary education workforce (in the upper part of the graph), and also which countries have a rapidly ageing one (on the right hand side of the graph). Only a few countries have a negative annual change, indicating a teaching workforce that is growing younger: Belgium, Canada, Chile, Ireland, Luxembourg and, especially, the United Kingdom. These countries have been able to develop teacher recruitment policies which have resulted in a relatively young workforce which is still rejuvenating itself. On the other side are the countries with a relatively old and still ageing teacher population, such as Italy and Estonia, and countries with a still relatively young but rapidly greying secondary school workforce, such as Portugal, Slovenia and Spain.

1. For countries where the data for 2000 were not available, the oldest available data were used. The annual change was calculated over the years for which data were available. 


\section{Figure 3. Average age and annual change in the age of secondary school teachers (2000-11)}

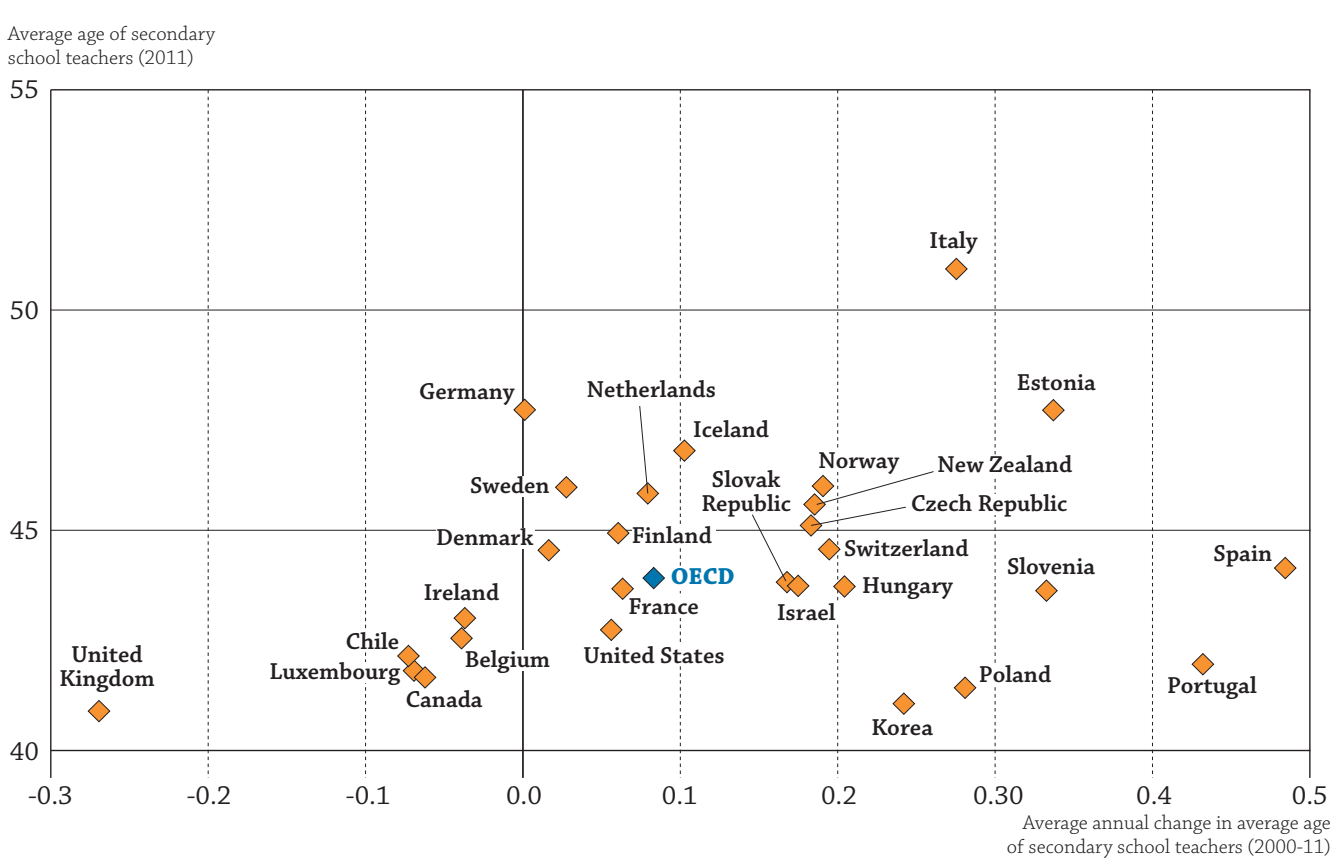

Source: OECD Education Database (available at http://stats.oecd.org).

On average across OECD countries the annual change in the average age of secondary school teachers between 2000 and 2011 was 0.083 . This means that every year the average age of secondary school teachers increased by approximately one month.

\section{Will more women teachers help?}

On average across OECD countries, $82 \%$ of teachers at the primary level, $68 \%$ at the lower secondary level, and $56 \%$ at the upper secondary level are women. The female teaching workforce on average is younger than its male counterpart. In the past, the replacement of male teachers with female colleagues thus reduced the average age of the teaching workforce as a whole or at least slowed down the pace of its ageing. But the female

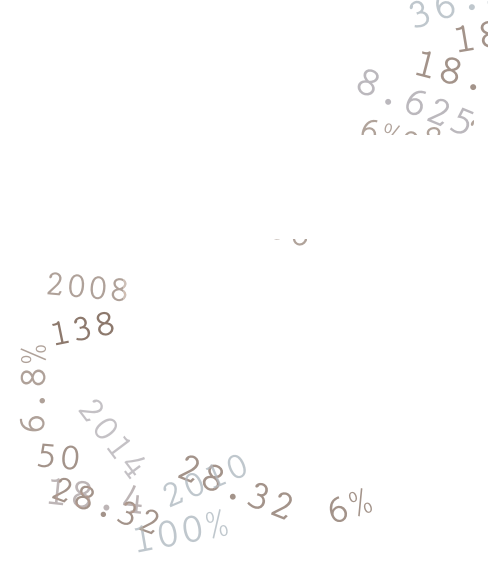
teaching workforce is now ageing slightly faster than that of the male workforce. The average age difference between male and female teachers has decreased from 1.3 years in 2000 to 0.9 in 2011 for primary education, and from 1.8 years to 1.5 in secondary education. The percentage of teachers over 50 years old is also increasing faster among female than male teachers.

The result is that the rejuvenating effect on the teaching workforce as a whole of recruiting more female teachers has completely disappeared. Increasing the relative share of women in the teaching workforce no longer has a positive impact on the age distribution of the teaching workforce. On the contrary, there is now a positive countrylevel correlation of 0.25 between the percentage of women in the teaching workforce in primary education and the average age of the primary education workforce as a whole. 


\section{EDUCATION INDICATORS IN FOCUS}

education data education evidence education policy education analysis education statistics

\section{Policy implications}

The policy implications of an ageing teaching workforce are quite significant. In the foreseeable future the need to replace large numbers of retiring teachers with new recruits might aggravate already looming teacher shortages. This will put even more strain on governments' ambitions to recruit more high-performing students into the teaching profession. Recruitment problems might mean that teachers are overloaded with instructional and administrative work, unable to meet student needs, and sometimes required to teach subjects outside their expertise. Short-term responses, such as lowering qualification requirements for entry to the profession, raise concerns about the quality of teaching and learning. Too many older teachers might also have a negative impact on the system's capacity for innovation. Older teachers are also probably further removed from the world and culture of their students. Finally, a skewed age distribution in itself generates an upward pressure on salaries overall and has various secondary effects on salaries and working conditions.

Governments should prepare for the consequences of an ageing teaching work force by strengthening their policies to make teaching an attractive career choice, revising the perverse effect of salary scales, designing compensation schemes that match the demand for teachers, and making teaching careers more attractive and diversified. It is no wonder that the United Kingdom, which launched an ambitious recruitment campaign around the year 2000, now has one of the youngest teaching workforces in the OECD (Schleicher, 2011, Box 1.2). At the same time, governments should actively address the training and professional development needs of older cohorts of teachers.

\section{References}

Jensen, B. et al. (2012), The Experience of New Teachers: Results from TALIS 2008, OECD Publishing, Paris, http://dx.doi.org/10.1787/9789264120952-en. OECD (2013a), Education at a Glance 2013: OECD Indicators, OECD Publishing, Paris, http://dx.doi.org/10.1787/eag-2013-en.

OECD (2013b), Health at a Glance 2013: OECD Indicators, OECD Publishing, Paris, http://dx.doi.org/10.1787/health_glance-2013-en.

OECD (2011), "Ageing Central Government Workforce", in Government at a Glance 2011, OECD Publishing, Paris, http://dx.doi.org/10.1787/gov_ glance-2011-29-en.

OECD (2005), Teachers Matter: Attracting, Developing and Retaining Effective Teachers, Education and Training Policy, OECD Publishing, Paris, http://dx.doi.org/10.1787/9789264018044-en.

Schleicher, A. (2012), Preparing Teachers and Developing School Leaders for the 21st Century: Lessons from around the World, OECD Publishing, Paris, http://dx.doi.org/10.1787/9789264174559-en.

Schleicher, A. (2011), Building a High-Quality Teaching Profession: Lessons from around the World, OECD Publishing, Paris, http://dx.doi.org/ 10.1787/9789264113046-en.

The bottom line: The teaching workforce continues to age at a high pace, skewing the age distribution among teachers, in some countries quite dramatically. This may have important consequences for teacher recruitment, salary and retraining costs, as well as for the adoption of innovation, and may distance teachers from the lives of their students. Governments should intensify their efforts to make teaching an attractive career choice and prepare for the need for mass replacements in the coming years.

\section{For more information}

OECD (2013), Education at a Glance 2013: OECD Indicators, OECD Publishing, Paris.

Contact

Dirk Van Damme (Dirk.Vandamme@oecd.org)

\begin{tabular}{ll} 
Visit & Coming next month \\
www.oecd.org/edu/eag.htm & How much are teachers paid? \\
PISA in Focus & \\
\hline Teaching in Focus & \\
\hline
\end{tabular}

Photo credit: @ Ghislain \& Marie David de Lossy/Cultura/Getty Images

This paper is published under the responsibility of the Secretary-General of the OECD. The opinions expressed and arguments employed herein do not necessarily reflect the official views of OECD member countries.

This document and any map included herein are without prejudice to the status of or sovereignty over any territory, to the delimitation of international frontiers and boundaries and to the name of any territory, city or area.

The statistical data for Israel are supplied by and under the responsibility of the relevant Israeli authorities. The use of such data by the OECD is without prejudice to the status of the Golan Heights, East Jerusalem and Israeli settlements in the West Bank under the terms of international law. 